\title{
Bone Marrow Contribution to Eosinophilic Inflammation
}

\author{
Judah A Denburg ${ }^{+}$, Lorna Wood, Gail Gauvreau, Roma Sehmi, \\ Mark D Inman, Paul M O'Byrne
}

\author{
Department of Medicine, McMaster University, 1200 Main Street West, Hamilton, Ontario, Canada L8N 3Z5
}

Allergen-induced bone marrow responses are observable in human allergic asthmatics, involving specific increases in eosinophil-basophil progenitors (Eo/B-CFU), measured either by hemopoietic assays or by flow cytometric analyses of CD34-positive, IL-3R $\alpha$-positive, and/or IL-5-responsive cell populations. The results are consistent with the upregulation of an IL-5-sensitive population of progenitors in allergen-induced late phase asthmatic responses. Studies in vitro on the phenotype of developing eosinophils and basophils suggest that the early acquisition of IL-5R $\alpha$, as well as the capacity to produce cytokines such as GM-CSF and IL-5, are features of the differentiation process. These observations are consistent with findings in animal models, indicating that allergen-induced increases in bone marrow progenitor formation depend on hemopoietic factor $(s)$ released post-allergen. The possibility that there is constitutive marrow upregulation of eosinophilopoiesis in allergic airways disease is also an area for future investigation.

Key words: hemopoiesis - asthma - inflammation - IL-5 - eosinophils - basophils

The development of airway inflammation occurs in association with the upregulation of cytokines by several cell populations within airways tissues. This leads to recruitment of inflammatory cells via several complex and interacting mechanisms. Since some cytokines produced by the airways following allergen possess hemopoietic activity, we hypothesized that after release by the airway they may act on the bone marrow to increase inflammatory cell production.

\section{PERIPHERAL BLOOD EOSINOPHIL-BASOPHIL PRO- GENITORS}

Atopy is associated with higher numbers of eosinophil-basophil progenitors, as measured by colony assays of human blood: in atopics there are greater numbers of eosinophil-basophil colonyforming units (Eo/B-CFU) (Denburg et al. 1985, Otsuka et al. 1986) and CD34+ cells (Sehmi et al. 1996) than in non-atopic controls. Likewise, during an acute exacerbation of asthma, there is a significant rise in blood Eo/B-CFU, which falls upon clinical resolution of the exacerbation induced by inhaled corticosteroids (Gibson et al. 1990). Patients with allergic rhinitis show seasonal fluctuations in blood Eo/B-CFU (Otsuka et al. 1986, Linden et al. 1994), and subjects with late asthmatic responses following allergen inhalation demon-

\footnotetext{
${ }^{+}$Corresponding author. Fax: +905-521.4971. E-mail: denburg@fhs.mcmaster.ca Received 3 September 1997 Accepted 30 September 1997
}

strate significant increases in circulating Eo/B-CFU and CD $34^{+}$cells at $24 \mathrm{hr}$ (Gibson et al. 1991, Sehmi et al. 1997).

\section{BONE MARROW EOSINOPHIL-BASOPHIL PROGENI- TORS}

Canine bone marrow myeloid progenitor cells (GM-CFU) increase $24 \mathrm{hr}$ after inhalation of Ascaris suum antigen (Woolley et al. 1994), especially when it is associated with the development of hyperresponsiveness or airways inflammation (Inman et al. 1996). With regard to human bone marrow progenitors, the phenotype of marrow $\mathrm{CD} 34^{+}$progenitor cells found in atopics (Sehmi et al. 1996) was further explored using allergen inhalation in subjects with late asthmatic responses, airway hyperresponsiveness and airway eosinophilia. This challenge provokes significant increases in marrow Eo/B-CFU (Wood et al. 1996), and, in particular, an increase in IL-3R $\alpha(+)$ or IL$5 \mathrm{R} \alpha(+) \mathrm{CD} 34^{+}$cells. These observations are in agreement with our observations of the upregulation of an IL-5-sensitive population of progenitors in allergen-induced late phase responses (Sehmi et al. 1996).

\section{PHENOTYPE OF EOSINOPHIL-BASOPHIL PROGENI- TORS}

Studies on the phenotype of eosinophil-basophil progenitors indicate an orderly sequence of acquisition of markers. Pluripotent progenitors, bearing CD34 alone, are found in bone marrow and cord blood followed by $\mathrm{Fc}_{\varepsilon} \mathrm{RI}$ acquisition (Rottem et al. 1992, 1994), as well as both highand low-affinity $\mathrm{Fc}_{\varepsilon}$ Rs on HL-60 cells which can 
be induced to differentiate to basophils-eosinophils (Hutt-Taylor et al. 1988). Surface phenotype changes include the upregulation of CD23 and CD35, concomitant with downregulation of CD15 (Wong et al. 1996). Hybrid basophil-eosinophils found in cord blood cultures (Tanno et al. 1987) or in vitro by density gradient separation (Boyce et al. 1995,1996) may represent transitional forms of $\mathrm{Fc}_{\varepsilon} \mathrm{RI}-$ and $\mathrm{Fc}_{\varepsilon} \mathrm{RII}$-bearing granulocytes, explaining possible discrepancies among several studies regarding $\mathrm{Fc}_{\varepsilon} \mathrm{R}$ expression by eosinophils (Capron et al. 1995). Recently we have found that maturing eosinophils-basophils taken from atopic asthmatic subjects produce more GM-CSF and possibly IL-5 after allergen inhalation challenge in vivo. These observations support the concept of upregulation of an activated and differentiating eosinophil phenotype in allergic inflammation (Gauvreau et al. 1997).

\section{BONE MARROW CONTRIBUTION TO ALLERGY AND ASTHMA}

We have proposed the hypothesis that the origin of atopic disease may not be only in the airway but also reside in lineage skewing in the bone marrow (Denburg et al. 1996). Evidence obtained from patients undergoing bone marrow transplant suggests that an important determinant of atopic and asthmatic disease may be transferrable (Agosti et al. 1988), raising the possibility that part of the predisposition toward allergic inflammation may be due to a propensity of progenitors in atopic bone marrow to differentiate preferentially as eosinophils/basophils. Indeed, in mice with a genetic predisposition to airway hyperresponsiveness, a significant component of airway hyperresponsiveness is transferrable by bone marrow transplantation (De Sanctis et al. 1996).

\section{HEMOPOIETIC CYTOKINES AS THERAPEUTIC TAR- GETS IN ASTHMA/ALLERGY}

Since inhaled corticosteroids can reduce circulating eosinophils, basophils and Eo/B-CFU both in vitro (Denburg et al. 1994) and in vivo (Gibson et al. 1990), as well as prevent increases in canine bone marrow GM-CFU following allergen challenge (Woolley et al. 1994), there may be a systemic effect of inhaled steroids on the marrow that is important in reducing airway inflammation. This would imply that hemopoietic mechanisms are involved in the pathogenesis of chronic airways inflammation, and that blocking certain eosinophilopoietic signals such as IL-3 or IL-5 might be therapeutically useful in asthma or other eosinophilic airways inflammatory reactions. Treatment with an antibody to IL-5 can indeed block allergen-induced eosinophilia and airway hyperresponsiveness for prolonged periods (Kung et al. 1995, Mauser et al. 1995) depending on the dose of antibody given. A more complete understanding of the role of the bone marrow may provide the basis for the development of novel therapeutic interventions in allergy and asthma.

\section{REFERENCES}

Agosti JM, Sprenger JD, Lum LG, Witherspoon RP, Fisher LD, Storb R, Henderson WR 1988. Transfer of allergen-specific IgE-mediated hypersensitivity with allogeneic bone marrow transplantation. $N$ Engl J Med 319: 1623-1628.

Boyce JA, Friend D, Gurish MF, Austen KF, Owen WF 1996. Constitutive production of granulocyte/macrophage colony-stimulating factor by hypodense mononuclear eosinophils developed in vitro from hybrid eosinophil/basophil granulocytes. Proc Natl Acad Sci USA 93: 2436-2441.

Boyce JA, Friend D, Matsumoto R, Austen KF, Owen WF 1995. Differentiation in vitro of hybrid eosinophil/basophil granulocytes: autocrine function of an eosinophil developmental intermediate. J Exp Med 182: 49-57.

Capron M, Soussi Gounni A, Morita M, Truong MJ, Prin L, Kinet JP, Capron A 1995. Eosinophils: from low- to high-affinity immunoglobulin E receptors. Allergy 50(25 suppl): 20-23.

De Sanctis GT, Itoh A, Qin S, Green FYH, Grobholz JK, Maki T, Martin TR, Drazen JM 1996. Bone marrow transplantation partially confers genetically determined hyperreactivity in inbred mice. $A m J$ Respir Crit Care Med 153: A769 (abstr).

Denburg JA, Inman MD, Leber B, Sehmi R, O'Byrne PM 1996. The role of the bone marrow in allergy and asthma. Allergy 51: 141-148.

Denburg JA, Telizyn S, Belda A, Dolovich J, Bienenstock J 1985. Increased numbers of circulating basophil progenitors in atopic patients. J Allergy Clin Immunol 76: 466-472.

Denburg JA, Woolley M, Leber B, Linden M, O'Byrne P 1994. Basophil and eosinophil differentiation in allergic reactions. J Allergy Clin Immunol 94: 11351141.

Gauvreau GM, O'Byrne PM, Watson RM, Denburg JA 1997. GM-CSF regulation by differentiating eosinophils after allergen challenge. J Allergy Clin Immunol 99: S363 (abstr).

Gibson PG, Dolovich J, Girgis-Gabardo A, Morris MM, Anderson M, Hargreave FE, Denburg JA 1990. The inflammatory response in asthma exacerbation: changes in circulating eosinophils, basophils and their progenitors. Clin Exp Allergy 20: 661-668.

Gibson PG, Manning PJ, O'Byrne PM, Girgis-Gabardo A, Dolovich J, Denburg JA, Hargreave FE 1991. Allergen-induced asthmatic responses: Relationship between increases in airway responsiveness and increases in circulating eosinophils, basophils, and their progenitors. Am Rev Respir Dis 143: 331-335.

Hutt-Taylor SR, Harnish D, Richardson M, Ishizaka T, Denburg JA 1988. Sodium butyrate and a T lymphocyte cell line-derived differentiation factor in- 
duce basophilic differentiation of the human promyelocytic leukemia cell line HL-60. Blood 71: 209-215.

Inman MD, Denburg JA, Ellis R, Dahlback M, O’Byrne PM 1996. Allergen-induced increase in bone marrow progenitors in airway hyperresponsive dogs: regulation by a serum hemopoietic factor. $A m J$ Respir Cell Mol Biol 15: 305-311.

Kung TT, Stelts DM, Zurcher JA, Adams GK III, Egan RW, Kreutner W, Watnick AS, Jones H, Chapman RW 1995. Involvement of IL-5 in a murine model of allergic pulmonary inflammation: prophylactic and therapeutic effect of an anti-IL-5 antibody. Am J Respir Cell Mol Biol 13: 360-365.

Linden M, Svensson C, Andersson M, Greiff L, Andersson E, Denburg JA, Seidegård J, Persson CGA 1994. Increased numbers of circulating leucocyte progenitors in patients with allergic rhinitis during natural allergen exposure. Am J Respir Crit Care Med 149: A602 (abstr).

Mauser PJ, Pitman AM, Fernandez X, Foran SK, Adams GK III, Kreutner W, Egan RW, Chapman RW 1995. Effects of an antibody to interleukin-5 in a monkey model of asthma. Am J Respir Crit Care Med 152: 467-472.

Otsuka H, Dolovich J, Befus AD, Telizyn S, Bienenstock J, Denburg JA 1986. Basophilic cell progenitors, nasal metachromatic cells, and peripheral blood basophils in ragweed-allergic patients. J Allergy Clin Immunol 78: 365-371.

Rottem M, Barbieri S, Kinet JP, Metcalfe DD 1992. Kinetics of the appearance of $\mathrm{Fc}_{\varepsilon}$ RI-bearing cells in interleukin-3-dependent mouse bone marrow cultures: correlation with histamine content and mast cell maturation. Blood 79: 972-980.

Rottem M, Okada T, Goff JP, Metcalfe DD 1994. Mast cells cultured from the peripheral blood of normal donors and patients with mastocytosis originate from a CD34+/Fc epsilon RI-cell population. Blood 84: 2489-2496.

Sehmi R, Howie K, Sutherland DR, Schragge W, O’Byrne PM, Denburg JA 1996. Increased levels of CD34+ hemopoietic progenitor cells in atopic subjects. Am J Respir Cell Mol Biol 15: 645-654.

Sehmi R, Wood LJ, Watson R, O’Byrne PM, Denburg JA 1997. Increased expression of IL-5 receptor alpha-subunit on bone marrow derived $\mathrm{CD}_{3} 4^{+}$progenitors following allergen challenge in dual responder asthmatics. J Clin Invest (in press).

Tanno Y, Bienenstock J, Richardson M, Lee TDG, Befus AD, Denburg JA 1987. Reciprocal regulation of human basophil and eosinophil differentiation by separate T-cell-derived factors. Exp Hematol 15: 2433.

Wong DA, Valent P, Bettelheim P, Switzer J, Denburg JA 1996. Immunophenotypic analysis of HL-60 cells during basophilic differentiation. Int Arch Allergy Immunol 110: 252-260.

Wood LJ, Inman MD, Watson RM, Denburg JA, O'Byrne PM 1996. Changes in bone marrow progenitor cells following allergen challenge in mild asthmatic subjects. Am J Respir Crit Care Med (in press).

Woolley MJ, Denburg JA, Ellis R, Dahlback M, O’Byrne PM 1994. Allergen-induced changes in bone marrow progenitors and airway responsiveness in dogs and the effect of inhaled budesonide on these parameters. Am J Respir Cell Mol Biol 11: 600-606. 